\title{
KAJIAN PEMIKIRAN KEISLAMAN DAN KEBANGSAAN KH BISRI MUSTOFA REMBANGDALAM KITAB \\ SYI'IR NGUDI SUSILA
}

\author{
Agus Salim Chamidi \\ IAINU Kebumen \\ aschamidi@yahoo.co.id
}

\begin{abstract}
This article is a research about Book Syi'ir Ngudi Susila written by KH Bisri Mustofa Rembang. The book (kitab) explaines about susila (moral, ethics, akhlakul karimah). The author of the book is a kyai founded pesantren Raudhatut Thalibin Leteh Rembang, and also a famaous politician. Research aims to know contents of the book and to find the author's Islamic thoughts. Results refer those, (1)habitus and modal owned by the author (agent) much influence contents of the book, (2)this book is as a form of the santri's cultural reproduction efforts, (3)through this book the author seems try to building profile of 'anak Islam' (santri, children of Islam) Nusantara whose have Islam ethics and nationality Indonesia.
\end{abstract}

Keywords: Kitab Syi 'ir Ngudi Susila, habitus, modal, cultural reproduction, santri

\begin{abstract}
Abstrak
Tulisan ini merupakan riset tentang Kitab Syi'ir Ngudi Susila karya KH Bisri Mustofa Rembang.Kitab ini menjelaskan susila (budi pekerti, akhlakul karimah). Penulis kitab merupakan seorang kyai pendiri pesantren Raudhatut Thalibin Leteh Rembang dan juga seorang politisi handal. Riset ini bertujuan untuk mengetahui isi kitab dan menemukan pemikiran keIslaman penulis. Hasil riset menunjukkan bahwa, (1)habitus dan modal yang dimilik penulis (agen) banyak mempengaruhi isi kitab, (2)kitab ini merupakan wujud untuk upaya reproduksi kultural santri, (3)melalui kitab ini penulis nampaknya mencoba membangun profil 'anak Islam' (santri) Nusantara yang berakhlakul karimah sekaligus berwawasan kebangsaan Indonesia.
\end{abstract}

Katakunci: Kitab Syi’ir Ngudi Susila, habitus, modal, reproduksi budaya, santri

\section{A. Identifikasi}

Kitab yang diidentifikasi di sini adalah Kitab Syi'ir Ngudi Susilo karya KHBisri Mustofa yang ditulis di Rembang pada bulan Jumadil akhir 1373 Hijriyah.Identitas ini tertera pada halaman 16, halaman terakhir kitab ini. Bulan dan tahun tersebut jika dikonversi ke dalam bulan dan tahun Masehi sama dengan bulan Pebruari 1954.

Kitab ini terdiri dari 1 lembar halaman cover dan 16 halaman isi. Pada halaman cover tertulis judul/nama kitab, penulis, dan logo dan nama penerbit. Huruf yang digunakan adalah huruf Arab.Syi'ir Ngudi Susila, suka fitedah kanthi terwela, dening Kiyahi Bisyri Mushthofa Rembang (Syair Ngudi Susila,untuk petunjuk yang jelas, oleh Kyai Bisri Mustofa Rembang). Adapun percetakan dan penerbitnya adalah Menara Kudus yang ditulis dalam huruf Arab.

Untuk halaman isi kitab, isi kitab berada di dalam pigura dua garis kotak.Terdapat 16 halaman isi kitab.Pada tiap halaman terdapat angka urutan halaman yang tertera di luar pigura kotak, di bagian tengah di tepi atas.Angka halaman menggunakan angka Arab. Angka urutan halaman itu diapit oleh dua kata dari judul kitab, yaitu, kata 'ngudi' di sudut kanan dan kata 'susila' di sudut kiri. Kedua kata ini menggunakan huruf Arab pegon.Masih di luar pigura kotak, di bagian bawah, tepi bawah sudut kiri terdapat sebuah kata berbahasa Arab pegon. Kata ini merupakan kata lanjutan yang tertulis pada halaman berikutnya.

Volume: 2 NO. 2 .Tahun 2018

Manajemen Pendidikan Islam dan social

ISSN On_Line: 2580-9385

ISSN Cetak : 2581-0197

Jurnal Cakrawala IAINU Kebumen, Manajemen Pendidikan Islam (MPI) 
Bagian Pembuka isi kitab berupa lafadz bismillaahir-rahmaanirrahiim dengan menggunakan huruf Arab. Di bawahnya terdapat dua baris shalawat Nabi SAW, shalaatullaahi maa laa hat kawaakib - pada baris pertama - 'ala ahmadu khairi man rakibannajaaib- pada baris kedua. Nampaknya kedua baris shalawat ini menjadi kunci lagu untuk lagu syair-syair di bawahnya. Shalawat ini nampaknya juga akan menjadi baris bait yang diulang-ulang.Masih pada bagian Pembuka, di bawah 2 baris shalawat terdapat 24 baris syair berhuruf Arab pegon. adalah:

Selanjutnya terdapat 8 bagian yang juga menggunakan huruf Arab pegon. 8 bagian itu

1. bab ambagi wektu(bab membagi waktu) berisi 14 baris

2. ing pamulangan (di tempat belajar), 12 baris

3. mulih saking pamulangan(pulang dari tempat belajar), 4 baris,

4. ana ing umah (berada di rumah), 10 baris

5. karo guru(kepada guru), 6 baris

6. ana tamu (ada tamu), 16 baris

7. sikep lan lagak(sikap dan tindakan), 26 baris

8. cita-cita luhur (cita-cita mulia), 46 baris.

Jumlah baris pada 8 bagian ini adalah 134 baris. Adapun penutup hanya berupa tulisan kata 'tammat' dalam huruf Arab. Dengan demikian, jumlah keseluruhan dalam kitab ini adalah 160 baris bait syair.

\section{Bagian 1, Bagian Pembuka}

Bagian Pembuka, selain lafadz basmallah dan shalawat Nabi adalah syair berikut yang tercetak miring.Adapun di belakangnya merupakan upaya penulis untuk menterjemahkannya.Bagian ini berada pada halaman 1-3, terdiri dari 26 baris.Dari 26 baris ini penulis mencoba membagi menjadi 7 subbagian sehingga tiap subbagian terdiri dari 4 baris.Khusus subbagian shalawat, penulis mencoba menuliskannya dua kali.Hal ini bertujuan untuk memudahkan dalam praktek mensyairkannya.

\section{Shalaatullaahi maa laa hat kawaakib}

'ala ahmadu khairi man rakibannajaaib

Shalaatullaahi maa laa hat kawaakib

'ala ahmadu khairi man rakibannajaaib

Iki syiir kanggo 'bocah' lanang wadon - ini syair untuk anak lelaki perempuan

Nebihake ingkah laku ingkang awon - menjauhkan perilaku yang jelek

Sarta nerangake budi kang perayoga - serta menjelaskan budi yang baik

Kangge dalan pada melebu ing uwarga - untuk jalan masuk ke sorga.

Bocah iku wiwit ngumur pitung taun - anak itu sejak berumur tujuh tahun

Kudu ajar tata keben ora getun - harus ajar tatakrama agar tak menyesal

Kudu tresna ring ibune kang ngerumati - harus cinta ibu yang merawat

Kawit cilik marang bapa kang gemati - sejak kecil pada ayah yang menjaga

Volume: 2 NO. 2 .Tahun 2018

Manajemen Pendidikan Islam dan social

ISSN Cetak : 2581-0197

Jurnal Cakrawala IAINU Kebumen, Manajemen Pendidikan Islam (MPI) 
Ibu bapa rewangana lamon repot -ayah ibu bantulah jika kerepotan

Aja kaya wong gemagus ingkang wangkot - jangan seperti orang bergaya keterlaluan

Lamon bapa ibu perentah enggal tandang - jika ayah ibu memerintah segera dilakukan

Aja bantah aja sengul aja mampang - jangan membantah jangan berungut jangan pula malas

Andap asor ing wong tuwa najan liya - rendah hati pada orang tua lainnya

Tetepana aja kaya raja kaya - tetaplah jangan seperti hewan piaraan

Gunem alus alon lirih ingkang terang - bicara halus pelan merendah namun tetap yang jelas

Aja kasar aja misuh kaya bujang - jangan kasar jangan mengomel seperti anak liar jalanan

Yen wong tuwa lenggah ngisor siro aja - jika orang tua duduk di bawah, janganlah

Pisan lungguh duwur kaya jamajuja - sekali-kali duduk di atas bak orang tidak tahu tatakrama

Yen wong tuwa sare aja geger guyon - kalau orangtua sedang tidur jangan ribut

Lamon sira nuju maca kudu alon - jika kamu sedang membaca cukup pelan saja

Lamon siro liwat ing ngarepe - jika kamu lewat di depannya

Kudu nuwun amit sarta depe-depe - harus pamit dan mohon ijin

Lamon ibu bapa duka becik meneng - jika ayah ibu marah lebih baik diam

Aja melu padon uga aja gereneng - jangan ikut marah juga jangan mengomel.

\section{Bagian 2, Bab Ambagi Wektu (Bab Membagi Waktu)}

Bagian ini berada pada halaman 3 dan 4.Bagian ini berisi 14 baris.Dalam penulisannya, penulis mencoba membaginya dalam subbagian dengan 4-4-4-2.Subbagian terakhir dapat dilagukan berulang.

Dadi bocah kudu ajar bagi zaman - jadi anak haru ajar membagi waktu Aja pijer dolan nganti lali mangan - jangan sebab dolan sampai lupa makan Yen wayahe shalat aja tunggu perentah - jika waktu shalat jangan nunggu diperintah Enggal tandang cekat-ceket aja wegah - cepat lakukan jangan malas

Wayah ngaji wayah sekolah sinau - waktu mengaji waktu sekolah belajar Kabeh mau gatekake kelawan tuhu - semuanya itu perhatikan dengan serius Kenthong subuh enggal tangi nuli adus - kentong subuh cepat bangun terus mandi Wudlu nuli shalat khusyu ingkang bagus - wudlu terus shalat yang khusyu yang bagus

Rampung shalat tandang gawe apa bae - usai shalat melakukan kerja apa saja Kang perayoga kaya nyaponi umahe - yang bagus seperti menyapu rumahnya Lamon ora iya maca-maca qur'an - jika tidak yabaca-bacalah al-qur'an Najan namung sithik dadiya wiridan - walau sedikit jadikanlah kebiasaan

Budal ngaji awan bengi sekabehe - usai mengaji siang malam semuanya Tata kerama lan adabe pada bae - tatakrama dan adabnya itu sama saja.

\section{Bagian 3, Ing Pamulangan (Di Tempat Belajar)}

Volume: 2 NO. 2 .Tahun 2018

Manajemen Pendidikan Islam dan social 
Bagian ini terdiri dari 12 baris. Selanjutnya akan dibagi menjadi 3 subbagian. Bagian ini berada pada halaman 4-5.

Lamon arep budal menyang pamulangan - bila akan berangkat ke tempat belajar Tata-tata ingkang rajin kang resikan - tata-tata yang rajin yang menjaga kebersihan Nuli pamit ibu bapa kanthi salam - lalu pamit ayah ibu dengan bersalam Jawab ibu bapa 'alaikumussalam - jawaban ayah ibu 'alaikumussalam

Disangoni akeh sithik kudu diterima - diberi sangu banyak sedikit diterima Supaya ing tembe dadi wong utama - agar nantinya jadi orang yang utama Ana pamulangan kudu tambah gati-ada di tempat belajar harus cermat selalu Numpa piwulangan ngilmu kang wigati - menerima pelajaran ilmu yang cermat

Ana kelas aja ngantuk aja guyon - di kelas jangan ngantuk jangan bergurauan Wayah ngaso kena aja mene guyon - saat istirahat boleh tapi jangan guyon berlebihan Karo kanca aja bengis aja judas - dengan teman jangan bengis jangan judes Mundak diwadani kanca ora waras - biar tidak dijuluki teman sebagai tidak waras.

\section{Bagian 4, Mulih Saka Pamulangan (Pulang dari Tempat Belajar)}

Bagian ini berada pada halaman 5-6.Bagian ini hanya memiliki 4 baris.

Bubar saking pamulangan enggal mulih - bubar dari tempat belajar cepatlah pulang Aja mampir-mampir dolan selak ngelih - jangan suka mampir dolan keburu lapar Tekan umah nuli salin sandangane - sampai rumah teruslah ganti pakaian Kudu pernah rajin rapi aturane - harus selalu rajin rapi pula aturannya.

\section{Bagian 5, Ana ing Umah (Berada di Rumah)}

Bagian ini berada pada halaman 6-7.Bagian ini berisikan 10 baris.Dalam penulisannya, penulis mencoba membagi dengan 4-4-2.

Karo dulur konco ingkang rukun bagus - dengan teman saudara yang rukun Aja kaya kucing belang rebut tikus - jangan seperti kucing belang rebutan tikus Dadi tuwa kudu weruh ing sepuhe - yang tua paham ketuaannya Dadi enom kuru rumangsa bocahe - yang muda paham kemudaannya

Lamon bapa ngalim pangkat sugih jaya - jika ayah alim berpangkat kaya berjaya Sira aja kulalungkung ring wong liya - kamu jangan arogan dengan orang lain Pangkat gampang minggat sugih kena mulih - pangkat bisa minggat kaya bisa kembali Ngalim iku gampang oleh molah malih - alim itu gampang bolak-balik

Rikala sira madep ring wong liya - saat kamu menghadap orang lain Kudu ajer aja merengut kaya baya - harus lembut jangan cemberut seperti buaya

\section{Bagian 6, Karo Guru (Kepada Guru)}

Volume: 2 NO. 2 .Tahun 2018

Manajemen Pendidikan Islam dan social ISSN On_Line: 2580-9385

ISSN Cetak : 2581-0197

Jurnal Cakrawala IAINU Kebumen, Manajemen Pendidikan Islam (MPI) 
Bagian ini berada pada halaman 7.Bagian ini berisikan 6 baris.Dalam penulisannya, penulis mencoba membagi dengan 4-2.

Marang guru kudu tuhu lan ngabekti - pada guru harus taat dan berbakti

Sekabehe perentah bagus kudu dituruti - semua perintah bagus harus diikuti

Piwulange ngertenana kanthi ngudi - pelajaran pahamilah dengan baik

Nasehate tetepana ingkang merdi - nasehat tetapilah dengan dijalani

Larangane tebihana kanthi yekti - larangan jauhilah dengan benar

Supaya ing tembe sira dadi mukti - agar kemudian kami jadi mulia

\section{Bagian 7, Ana Tamu (Ada Tamu)}

Bagian ini berada pada halaman 8-9.Bagian ini berisikan 16 baris.Dalam penulisannya, penulis mencoba membagi dengan 4-4-4-4.

Tetkalane ibu bapa nampa tamu - saat ayah ibu menerima tamu

Aja biyayaan tingkah polahmu - jangan sembarangan tingkahmu

Aja nyuwun duit wedang lan panganan-jangan minta uang dan makanan

Rewel beka kaya ora tau mangan - rewel kampungan kayak tak pernah makan

Lamon banget butuh kudu sabar disik - jika amat butuh harus sabar dulu

Nganti tamu mundur dadi sira becik - nunggu tamu pulang jadi kamu baik

Arikala pada bubaran tamune - saat bubar sudah tamunya

Aja nuli rerebutan turahane - janganlah rebutan lebihan sisanya

Kaya keting rerebutan najis tiba-kayak keting berebutan najis jatuh

Gawe malu lamon dideleng wong jaba - bikin malu jika dilihat orang luar

Kejaba yen bapa dawuh he anakku - kecuali jika ayah menyuruh hai anakku

Iku turahe wong ngalim kiyahiku - itu sisa orang alim kyaiku

Bagi rata sakdulurmu keben kabeh - bagi rata pada saudaramu biar semua

Ketularan ngalim sugih banda akeh - tertular alim kaya banyak harta

Niyat ira nuperih berkahe wong mulya - niatmu dapat berkah orang mulia

Ora niyat rebut turahe wong liya - bukan niat rebutan sisa orang lain

\section{Bagian 8, Sikep lan Lagak (Sikap dan Tindakan)}

Bagian ini berada pada halaman 9-12.Bagian ini berisikan 26 baris.Dalam penulisannya, penulis mencoba membagi dengan $(4 \times 6)$ dan 2 baris.

Anak Islam iku mangsa kudu awas - anak Islam setiap saat harus waspada Aja nganti lena mengko mundak tiwas - jangan sampai terlena biar tak tewas

Luru ngilmu iku perlu nanging budi - cari ilmu itu perlu tetapi budi pekerti

Adab Islam kudu tansah dipersudi - adab Islam harus selalu dikedepankan

Akeh bocah pinter nanging ora bagus - banyak anak pintar tapi tidak baik

Budi pekertine sebab do gemagus - budi pekertinya sebab suka nakal

Volume: 2 NO. 2 .Tahun 2018

Manajemen Pendidikan Islam dan social

ISSN Cetak : 2581-0197

Jurnal Cakrawala IAINU Kebumen, Manajemen Pendidikan Islam (MPI) 
Ring wong tuwa mbok ngergani mbok ngajeni - dengan orangtua hargailah hormatilah

Sajak pinter dewe langka kang madani - berlagak pintar sendiri tiada tanding

Jare niku caranipun sakpuniko - katanya itulah model zaman sekarang

Ora ngono dudu intelek merdeka - bukan begitu itu bukan intelek merdeka

Ngagem belangkon serban sarung dadi gujeng - pakai blankon surban sarung jadi ketawaan

Jare ora kebangsaan ingkang majeng - katanya tidak kebangsaan yang maju

Sawang iku Pangeran Dipanegara - lihatlah itu Pangeran Dipanegara

Imam Bonjol Tengku Ngumar kang kuncara - Imam Bonjol Tengku Umar yang terkenal

Kabeh pada bela bangsa lan Negara - semua membela bangsa dan negara

Pada ngagem destar pantes yen perwira - memakai destar pantaslah jika perwira

Gujeng serban sasat gujeng Imam Bonjol - mengetawai surban ya mengetawai Imam Bonjol

Sak kancane he anakku aja tolol- juga temannya hai anakku janganlah tolol

Timbang gundul apa ora luwih bagus - daripada gundul apa itu tidak lebih baik

Ngagem tutup sirah kaya raden bagus - pakai penutup kepala kayak raden bagus

Kala-kala pamer rambut sak karepmu - sewaktu-waktu boleh pamer rambutmu

Nanging kudu eling papan serawungamu - tapi harus ingat tempat pergaulanmu

Kumpul muda beda karo pul yahine - bersama yang muda beda dengan bersama kyai

Nuju shalat gak pada melancong nujune - bershalat itu tak sama dengan melancong

Ora nuli melancong gundul shalat gundul - tidak lalu melancong gundul shalat gundul

Sowan maratuwa gundul nguyuh gundul - menghadap mertua gundul kencing pun gundul

\section{Bagian 9, Cita-cita Luhur (Cita-cita Mulia)}

Bagian ini berada pada halaman 12-16. Bagian ini berisikan 46 baris. Dalam penulisannya, penulis mencoba membagi dengan $(4 \times 11)$ dan 2 baris.

Anak Islam kudu cita-cita luhur - Anak Islam harus bercita-cita mulia

Keben dunya akhirate bisa makmur - biar dunia akhirat dapat makmur

Cukup ngilmu ngumume lan agamane - cukup ilmu umum dan agama

Cukup dunya kanthi bekti pengerane - cukup dunia dengan bakti pada Tuhan

Bisa mimpin sedulure lan bangsane - dapat memimpin saudara dan bangsa

Tumuju ring raharjan lan kemulyane - menuju sejahtera dan mulia

Iku kabeh ora gampang leksananae - itu semua tak mudah jalannya

Lamon ora kawit cilik ta citane - jika tak sedari kecil cita-citanya

Cita-cita kudu dikanthi gumergut - cita-cita harus diraih sekuatnya

Ngudi ngilmu sarta pekerti kang patut - cari ilmu dan pekerti yang patut

Kita iki bakal tinggal wong tuwa - kita ini akan meninggalkan orangtua

Ora kena ora kita mesthi mowa - mau tak mau kita harus dewasa

Lamon kita pada katekan sejane - jika kita dapat meraih cita

Ora liwat sira kabeh pemimpine - tidak lain kamu semua pemimpinnya

Volume: 2 NO. 2 .Tahun 2018

Manajemen Pendidikan Islam dan social

ISSN On_Line: $2580-9385$

ISSN Cetak : 2581-0197

Jurnal Cakrawala IAINU Kebumen, Manajemen Pendidikan Islam (MPI) 
Negaramu butuh menteri butuh mufti - negaramu butuh menteri juga mufti

Butuh qodi patih seten lan bupati - butuh qadi patih gubernur dan bupati

Butuh dokter butuh mister ingkang pinter - butuh dokter dan master pintar

Ngilmu agama kang nuntun laku bener - ilmu agama yang menuntun benar

Butuh guru lan kiyahi kang linangkung - butuh guru dan kyai mumpuni

Melu ngatur negarane ora kethung - ikut mengatur negara tanpa kecuali

Iki kabeh sapa maneh kang ngayahi - semua siapa lagi yang menempati

Lamon ora anak kita kang nyaguhi - jika bukan anak kita yang menyanggupi

Kejaba yen sira kabeh ridlo mbuntut - kecuali jika kalian rela mengekor

Selawase angon wedus nyekel pecut - hanya piara kambing pegang cemeti saja

Sira ridlo guncel cikar selamine - kalian rela selamanya dalam susah

Kafir ira mentul-mentul lungguhane - kekafiranmu mengkhawatirkan

Ora nyela angon wedus numpak cikar -mendingan piara kambing naik kuda

Asal cita-cita ngilmu bisa nenggar - asal cita-cita ilmu dapat tergelar

Nabi kita kala timur pangon menda - Nabi kita saat muda piara kambing

Ing tembene pangon jalma kang sembada - kemudian menjadi orang berwibawa

Abu Bakar Sidiq iku bakul masar - Abu Bakar Sidiq itu penjual di pasar

Nanging nata masyarakat ora sasar - tapi dapat menata masyarakat tidak kesasar

Ngali Abu Tholib bakul kayu bakar - Ali bin Abi Thalib jual kayu bakar

Nanging tangkas yen dadi panglima besar - tapi tangkas jadi panglima besar

Wahid Hasyim santri pondok kok sekolah - Wahid Hasyim santri pondok juga sekolah

Dadi menteri karo liyan ora kalah - jadi menteri pun tidak kalah

Kabeh mau gumantung ing seja luhur - semuanya tergantung niat mulia

Kanthi ngudi ngilmu sarta laku jujur - cari ilmu dan berlaku jujur

Tekan kene pungkasane syi'ir iki - sampai sinilah akhir syair ini

Larikane wolulima kurang siji - barisnya delapan lima kurang satu

Muga-muga seja kita sinembadan - semoga niat kita terkabulkan

Deneng Allah ingkang nurunake udan - oleh Allah yang menurunkan hujan

Pinaringan taufiq sarta hidayah - mendapatkan taufiq dan hidayah

Dunya akhirate sihhah wa 'afiyah - dunia akhirat sehat wal afiat

Amiin amiin amiin amiin amiin amiin - amin

Falhamdu lil-ilaahi rabbil- 'alamiin - segala puji bagi Tuhan Pemelihara Alam

\section{B. Riset Terdahulu dan Kajian Teoritis}

Sejumlah orang sudah mencoba meneliti kitab syair Ngudi Susila.Syaiful Fathoni misalnya, mencoba meneliti kitab ini untuk mengetahui nilai-nilai akhlak mulia dan isi

Volume: 2 NO. 2 .Tahun 2018

Manajemen Pendidikan Islam dan social

ISSN On_Line: 2580-9385

ISSN Cetak : :2581-0197

Jurnal Cakrawala IAINU Kebumen, Manajemen Pendidikan Islam (MPI) 
kandungan syair ${ }^{1}$. Sedangkan Moh. Hasim dalam risetnya memandang bahwa kitab ini berisikan ajaran moral dasar untuk membentuk karakter anak yang memiliki rasa hormat dan tanggung jawab ${ }^{2}$.Kitab ini diterbitkan pada tahun 1954. Dalam tulisan Fejrian ${ }^{3}$, pada Pemilu 1955 KH Bisri Mustofa terpilih menjadi anggota konstituante ${ }^{4}$ yang merupakan wakil dari Partai NU. Kitab ini merupakan salah satu dari 176 buku/kitab karya beliau.

Yang menarik adalah bahwa kitab syair Ngudi Susila ini terbit dan banyak membicarakan persoalan budi pekerti (susila) pada suatu kurun historis dimana KH Bisri Mustofa berada pada wilayah (arena) politik Indonesia jelang Pemilu 1955. Bahkan dalam tulisan Fejrian disebutkan bahwa KH Bisri Mustofa dikenal sebagai seorang orator yang handal, kritis, segar, sopan, dan humoris. Kyai ini mengenyam pendidikan pesantren dengan mengaji pada Kyai Cholil Kasingan Rembang yang kemudian menjadi mertuanya, kemudian juga mengaji ke Mekah kepada banyak guru disana, seperti Syaikh Umar Khamcan, Syaikh Ali Maliki, Syaikh Hasan Masysyath, Sayyid Alwi Al Maliki, dan lainnya.Kyai ini dikenal sebagai pendiri Pondok Pesantren Raudhatul Thalibin Leteh Rembang.Pendek kata, Kitab Ngudi Susila lahir dari sosok santri, kyai, orator handal, dan politisi. Tentu ini menjadi sangat menarik sebagai sebuah kajian, dan inilah yang membedakan tulisan saya dengan tulisan sebelumnya. Lebih jauh, kitab ini akan saya telaah untuk memahami pemikiran keIslaman dan kebangsaan Indonesia dari KH Bisri Mustofa. Telaah atas pemikiran penulis kitab akan saya posisikan sebagai sebuah realitas praktis yang terwujud dalam sebuah kitab Syi'ir Ngudi Susila tersebut. Dengan kata lain, kitab itu adalah wujud praktis dari pemikiran KH Bisri Mutofa sang penulis atas suatu realitas sosial yang dihadapinya. Untuk itu, saya akan mencoba menelaah kitab itu dengan mempergunakan perspektif Pierre Bourdieu yang terkenal memiliki persamaan teori praktik: (Habitus $x$ Modal $)+$ Ranah $=$ Praktik $^{5}$.

Sebelum menguraikan pemikiran Pierre Bourdieu, penting di sini mengetahui pengertian santri sebab KH Bisri Mustofa banyak berkaitan dengan dunia santri. Masa mudanya pernah menjadi santri, dan kemudian ia pun mendirikan pondok pesantren tempat dimana para santri belajar mengaji. Adapun pengertian santri, menurut Agus Salim Chamidi ${ }^{6}$, adalah orang yang

${ }^{1}$ Syaiful Fathoni. 2015. Pendidikan Akhlak Anak Usia Sekolah Dasar menurut KH. Bisri Mustofa dalam Syair Ngudi Susila Pitedhah Kanthi Terwela.Tesis.Malang, Universitas Islam Negeri Malik Ibrahim. http://etheses.uin-malang.ac.id/id/eprint/5356 . L Lihat juga Dani Wiryanti. 2009. Syiir Ngudi Susila Karya Kiai Bisri Mustofa (Suatu Kajian Stilistika), Skripsi.Jurusan Sastra Daerah Fakultas

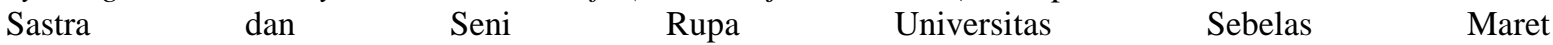
Surakarta.https://eprints.uns.ac.id/7011/1/103652909200909221.pdf , Mohamad Khamim Jazuli. 2017. NilaiNilai Pendidikan Akhlak dalam Kitab Syi’ir Ngudi Susilo Karya KH. Biri Mustofa.Skripsi . Jurusan Pendidikan Agama Islam Fakulta Tarbiyah dan Ilmu Keguruan IAIN Salatiga http://erepository.perpus.iainsalatiga.ac.id/1726/1/

${ }^{2}$ Moh.Hasim.2015. Ajaran Moral Syi’ir Ngudi Susilo dalam Membangun Karakter Anak. Jurnal Analisa Journal of Social Science and Religion.22 (2), hal 309-319.

${ }^{3}$ Fejrian Yazdajird Iwanebel. 2014. Corak Mistis dalam Penafsiran KH. Bisri Mustofa, Telaah Analitis Tafsir AlIbriz. Jurnal Rasail, 1(1), hal. 23-40

${ }^{4}$ Konstituante merupakan lembaga Negara Indonesia yang didirikan 9 November 1956, yang bertugas membuat Undang Undang Dasar atau konstitusi baru menggantikan Undang Undang Dasar Sementara (UUDS) 1950 sesuai amanat Pasal 134 UUDS 1950.

${ }^{5}$ Richard Harker, dkk. 2009. (Habitus x Modal) + Ranah = Praktik, Pengantar Paling Komprehensif kepada Pemikiran Pierre Bourdieu. Terjemahan Pipit Maizier, Yogyakarta, Jalasutra. Baca juga Kukuh Yudha Karnanta.2013. Paradigma Teori Arena Produki Kultural Sastra, Kajian terhadap Pemikiran Pierre Bourdieu. Jurnal Poetika, 1(1), hal.3-15. Mohammad Adib. 2012. Agen dan Struktur dalam Pandangan Pierre Bourdieu. Jurnal BioKultur, 1(2), hal. 91-110. Mangihut Siregar. 2016. Teori 'Gado-Gado' Pierre-Felix Bourdieu. Jurnal Studi Kultural, (1(2), hal. 79-82.

${ }^{6}$ Agus Salim Chamidi.2017.Membedah Identitas Santri. Jurnal An Nahdhah, 11(1), hal. 45-62.

Volume: 2 NO. 2 .Tahun 2018

Manajemen Pendidikan Islam dan social

ISSN On_Line: 2580-9385

ISSN Cetak : :2581-0197

Jurnal Cakrawala IAINU Kebumen, Manajemen Pendidikan Islam (MPI) 
mendalami dan menghayati Al Quran dan sunnah Nabi SAW, yang menteladani Nabi SAW yang memiliki perangai yang baik (uswatun khasanah) dengan etika yang luhur (khuluqin 'adhim), yang lazimnya santri itu berguru pada kyai (ulama, ajengan, buya, tuan guru), yang lazimnya pula menempatkan Al Quran, sunnah Nabi SAW, dan perangkat lainnya sebagai pijakan etika keIslamannya dan mengejawantahkannya dalam hidup dan kehidupannya di tengah masyarakat global mondial. Sedangkan menurut Ahmad Muhakammurohman ${ }^{7}$, santri adalah murid dari seorang kyai (guru, resi) yang biasanya menetap dalam satu tempat yang bernama pesantren (padepokan, asrama).Dengan demikian, KH Bisri Mustofa sebenarnya merupakan sosok yang selama hidupnya sangat dekat dengan dunia santri dan pesantren.

Adapun Pierre-Felix Bourdieu (1930-20202) merupakan pemikir sosial kelahiran Perancis.Rumusan teori praktik Bourdieu menempatkan peran praktis agen (actor, penulis kitab) dalam struktur sosial dengan membangun relasi antara habitus, modal, dan ranah (arena).Praktik yang dilakukan oleh agen, yang maujud dalam sebuah karya kitab misalnya, merupakan suatu produk dari relasi antara habitus, ranah, dan modal yang dimiliki dan dihadapinya. Praktek itu juga merupakan upaya reproduksi kultural yang dilakukan oleh agen dalam suatu ranah (arena) tertentu dengan berbasiskan pada habitus dan modal agen itu.

Agen adalah individu yang menjadi subyek sosial. Agen berkaitan dengan apa yang disebut agensi. Apabila agen mengacu pada pengertian individu, agensi menunjuk pada kemampuan individu itu dalam kaitannya dengan relasi-relasinya terhadap struktur sosial masyarakatnya. Dalam pemikiran Bourdieu, struktur sosial itu sendiri memiliki dua dimensi, yaitu, (1)struktur objektif yang merupakan struktur sosial yang dipahami pada umumnya, dan (2)struktur subjektif yang merupakan struktur sosial yang dipahami oleh individu itu. Dengan demikian, agen adalah individu yang memiliki kemampuan diri sebagai agensi, yang berhubungan relasional dengan strukturobyektif pada umumnya dan sekaligus berhubungan dengan struktur subyektif yang terbangun sesuai dengan kemampuan individual agen tersebut.

Struktur subyektif tersebut berkaitan dengan apa yang disebut sebagai habitus agen individu itu. Habitus merupakan sebuah sistem watak individu yang terbentuk dari proses belajar dan internalisasi diri terhadap struktur sosial budaya masyarakatnya. Habitus merupakan hasil pembatinan agen atas struktur obyektif menjadi struktur subyektif agen. Dengan kata lain, habitus merupakan kebiasaan individu agen yang bersifat khas dirinya, yang dihasilkan dari proses belajar dan pembatinan individu agen atas struktur sosial obyektif, yang menjadi struktur sosial subyektifnya, yang secara praktis muncul saat terjadi relasi-relasi sosial dengan struktur sosial budaya masyarakatnya dalam.

Agen itu dapat tampil, bersaing, bergulat, dan atau praktek berkarya nyata di dalam suatu arena (ranah, field) itu tentunya memiliki bekal diri yang disebut Bourdieu sebagai modal (capital), yaitu, sumber kekuatan dan kekuasaan yang dimiliki dan digunakan. Agen itu memiliki kekuatan sebab ia memiliki modal, dan sekaligus memiliki kekuasaan atas modal sebab ia berkuasa untuk dapat mempergunakan modal tersebut. Menurut Bourdieu, modalitu maujud berupa modal ekonomi, modal budaya, modal sosial, dan modal simbolik. Modal ekonomi dapat berupa alat-alat produksi, materi, dan uang yang dimiliki agen.Modal budaya dapat berupa kapasitas intelektual maupun warisan kultural yang dimiliki agen. Modal sosial dapat berupa jejaring sosial yang dimiliki agen terkait dengan struktur kekuasaan. Sedangkan modal simbolik dapat berupa simbol-simbol sosial yang memiliki otoritas dan legitimasi yang dimiliki agen. Dalam berhadapan dengan struktur sosial masyarakatnya, dapat diasumsikan

\footnotetext{
${ }^{7}$ Ahmad Muhakammurohman. 2014. Pesantren: Kiai, Santri, dan Tradisi. Jurnal Ibda' Jurnal Kebudayaan Islam, 12(2), hal 109-118.
}

Volume: 2 NO. 2 .Tahun 2018

Manajemen Pendidikan Islam dan social

ISSN On_Line: 2580-9385

ISSN Cetak : 2581-0197

Jurnal Cakrawala IAINU Kebumen, Manajemen Pendidikan Islam (MPI) 
bahwa semakin banyak dan besar modal yang dimiliki agen itu semakin besar peluang agen untuk membangun banyak relasi sosial, yang pada gilirannya agen tersebut dapat saja membangun dan memperoleh kekuasaan dominan.

Namun, asumsi di atas dalam praktek sosial masih tergantung juga pada apa yang disebut Bourdieu sebagai arena (field, ranah) sebagai ruang sosial dimana habitus dan modal itu praktis berkelindan. Arena itu merupakan wujud struktur sosial obyektif, atau realitas sosial yang dihadapi oleh agen dengan habitus dan modal yang dimilikinya, yang di dalamnya agen membuktikan siapa dirinya, bagaimana kapasitas ke-agensi-annya, dan bagaimana modal dan habitus agen tampil produktif. Dalam sebuah arena agen dapat saja dengan mudah memperkuat dirinya, akan tetapi dalam arena yang lain agen dapat saja mengalami pergulatan keras untuk memperkuat dirinya. Dalam sebuah arena yang bersifat internal agen dapat saja dengan mudah meningkatkan kapasitas dan dominasinya, akan tetapi dalam arena lain yang bersifat eksternal agen harus berjuang keras untuk membangun eksistensi dirinya dan memenangkan kontestasi. Dengan kata lain, bahwa sebuah arena mempunyai kebutuhan khas yang berbeda dengan arena lainnya.

Arena menghadirkan apa yang disebut Bourdieu sebagai kuasa simbolik (symbolic power) atau kekerasan simbolik (symbolic violence), yaitu, upaya-upaya agen untuk mengubah dan menciptakan realitas sebagai sesuatu yang harus dikenali dan diakui secara sah oleh orang lain. Upaya ini dilakukanmelalui mekanisme yang disebut Bourdieu sebagai doxa, yaitu, suatu kepercayaan yang bersifat fundamental sebagaimana dogma yang diterima begitu saja tanpa pertanyaan, yang secara mekanistik mengarahkan cara pandang orang lain sesuai dengan cara pandang agen. Cara pandang agen ini berbasiskan pada habitus agen itu sendiri dimana habitus ini merupakan bentukan dari struktur subyektif agen terhadap struktur obyektif (arena).Dengan demikian, kuasa simbolik sebagai upaya agen dengan mekanisme doxa itu merupakan perjuangan kelas agen di tengah arena yang dihadapinya.

\section{Pembahasan}

Kitab Syair Ngudi Susilo karya KH Bisri Mustofa merupakan sebuah karya yang dalam perspektif Bourdieu di sini ditempatkan sebagai realitas praktis.Kitab ini merupakan hasil karya praktis dari sosok agen yang bernama KH Bisri Mustofa, sosok yang pernah menjadi santri dan juga memiliki santri dalam pondok pesantrennya.Dengan kata lain, kitab ini merupakan wujud agensi atau kemampuan individual KH Bisri Mustofa sebagai agen dalam kaitannya dengan relasi-relasinya terhadap struktur sosial masyarakatnya.

KH Bisri Mustofa dikenal sebagai kyai dan sekaligus politisi.Dengan kata lain, agen memiliki identitas sosial sebagai kyai dan sekaligus politisi. Sebagai kyai, KH Bisri Mustofa adalah pendiri Pondok Pesantren Raudhatul Thalibin Leteh Rembang yang sampai kini ,masih berdiri. Sebagai politisi, KH Bisri Mustofa adalah anggota konstituante dari Partai Nahdlatul Ulama (NU) melalui Pemilihan Umum (Pemilu) 1955, anggota MPRS dari kalangan ulama setelah muncul Dekrit Presiden 1959, dan anggota MPR dari Jawa Tengah melalui Partai NU dalam Pemilu 1971.Sebagai kyai, arena yang dihadapinya adalah arena pondok pesantren, NU, dan kelas sosial santri yang relatif seragam.Sebagai politisi, arena yang dihadapinya adalah arena politik Indonesia era Presiden Soekarno dan kelas-kelas sosial yang beragam.

Habitus KH Bisri Mustofa adalah santri/kyai/ulama sekaligus politisi.Dari uraian di atas, modal KH Bisri Mustofa adalah:(1)modal budaya dengan kualifikasi yang diakui sebagai ulama; (2)modal simbolik dengan status sebagai pendiri pondok pesantren yang memiliki otoritas dan legitimasi yang jelas; (3)modal politik dengan prestasi sebagai anggota konstituante, anggota MPRS, dan anggota MPR; (4)modal sosial dengan banyak jejaring sosial, baik yang

Volume: 2 NO. 2 .Tahun 2018

Manajemen Pendidikan Islam dan social

ISSN On_Line: 2580-9385

ISSN Cetak : 2581-0197

Jurnal Cakrawala IAINU Kebumen, Manajemen Pendidikan Islam (MPI) 
berbasis pesantren dan NU maupun yang berbasis politik dan keIndonesiaan, dan (4)modal ekonomi dengan sejumlah pendapatan dan alat produksi. Dengan habitus dan modal tersebut, KH Bisri Mustofa rupanya mampu membuat karya sekitar 176 buku/kitab, yang di antaranya adalah Kitab Syair Ngudi Susila.

Kitab Syair Ngudi Susila sebagaimana sudah disebutkan di atas terdiri dari 9 bagian, yaitu, Pembuka, Bab Membagi Waktu, Di Tempat Belajar, Pulang dari Tempat Belajar, Berada di Rumah, Kepada Guru, Ada Tamu, Sikap dan Tindakan, dan Cita-Cita Mulia. Kitab ini banyak mengulas tentang budi pekerti mulia (akhlaqul karimah). Semuanya menggunakan huruf Arab pegon, kecuali beberapa lafadz asli berbahasa Arab.

Apabila memperhatikan penggunaan huruf Arab, baik bahasa Arab pegon maupun bahasa Arab asli, nampaknya KH Bisri Mustofa sebagai agen menempatkan Kitab Syair Ngudi Susila sebagai wujud ke-agensi-annya lebih sebatas untuk kalangan santri. Arena-nya adalah arena santri, pondok pesantren, dan NU.Hal ini dapat dipahami dari habitus dan modal KH Bisri Mustofa.

Selanjutnya dari 9 bagian kitab itu, saya mencoba membagi ke dalam dua kelompok kategoristik.Pembagian kelompok ini saya lakukan terkait dengan habitus dan modal yang dimiliki agen, yaitu:

1. Kelompok I adalah bagian Pembuka, Bab Membagi Waktu, Di Tempat Belajar, Pulang dari Tempat Belajar, Berada di Rumah, Kepada Guru, dan Ada Tamu. Ada 7 bagian dalam Kelompok I.

2. Kelompok II adalah bagian Sikap dan Tindakan dan bagian Cita-Cita Mulia. Ada 2 bagian dalam Kelompok II.

Pada Kelompok I, KH Bisri Mutofa nampaknya lebih banyak menampilkan habitus dan modal sebagai 'kyai'. Ke-kyai-annya mendominasi isi dan muatan syair-syair dalam Kelompok I. Pemahaman ke-kyai-an di sini menunjukkan bahwa agen mencoba menempatkan diri sebagai kyai bagi santri, guru bagi murid, sekaligus orangtua bagi anak. Tema besar dalam Kelompok I ini tentang pentingnya budi pekerti muliabagi santri, murid, anak.

Pada Kelompok II, KH Bisri Mustofa nampaknya lebih banyak menampilkan habitus dan modal 'kyai-politisi'. Ke-kyai-politisi-annya mendominasi isi dan muatan syair-syair dalam Kelompok II. Pemahaman 'kyai-politisi' di sini menunjukkan bahwa agen mencoba menempatkan dirinya sebagai kyai-politisi bagi kalangan umat Islam di Indonesia, khususnya masyarakat pesantren dan NU. Dalam bagian Sikep lan Lagak (Sikap dan Tindakan) dan bagian Cita-Cita Luhur (Cita-Cita Mulia), KH Bisri Mustofa mengawali syairnya dengan frasa khas: 'anak Islam'. Berbeda dengan bagian-bagian pada Kelompok I, bagian-bagian dalam Kelompok II menampilkan arena yang luas, dengan tema besarnya tetap tentang arti pentingnya budi pekerti mulia.Negara dan bangsa Indonesia menjadi arenanya.

Misalnya, pada Bab 8 tertulis: Sawang iku Pangeran Dipanegara, Imam Bonjol Tengku Ngumar kang kuncara, kabeh pada bela bangsa lan, pada ngagem destar pantes yen perwira. (Lihatlah itu Pangeran Dipanegara, Imam Bonjol Tengku Umar yang terkenal, semua membela bangsa dan Negara, memakai destar pantaslah jika perwira). Pada Bab 9 tertulis: Lamon kita pada katekan sejane, ora liwat sira kabeh pemimpine, negaramu butuh menteri butuh mufti, butuh qodi patih seten lan bupati, butuh dokter butuh mister ingkang pinter, ngilmu agama kang nuntun laku bener, butuh guru lan kiyahi kang linangkung, melu ngatur negarane ora kethung. (Jika kita dapat meraih cita, tidak lain kamu semua pemimpinnya, negaramu butuh menteri juga

Volume: 2 NO. 2 .Tahun 2018

Manajemen Pendidikan Islam dan social

ISSN On_Line: 2580-9385

ISSN Cetak : 2581-0197

Jurnal Cakrawala IAINU Kebumen, Manajemen Pendidikan Islam (MPI) 
mufti, butuh qadi patih gubernur dan bupati, butuh dokter dan master pintar, ilmu agama yang menuntun benar, butuh guru dan kyai mumpuni, ikut mengatur negara tanpa kecuali).

Meskipun kitab ini memuat nasehat tentang arti pentingnya budi pekerti mulia, akan tetapi nampaknya KH Bisri Mustofa berupaya untuk melakukan apa yang disebut di sini sebagai reproduksikultural santri. Dalam arena terbatas maupun arena luas Indonesia, KH Bisri Mustofa dengan habitus dan modalnya telah melakukan upaya reproduksi kultural santri melalui karya kitab ini.Kitab ini merupakan wujud dari praktek sosial agen yang di dalamnya sekaligus memuat reproduksi budaya santri berupa upaya-upaya pelestarian nilai-nilai budaya khas santri dan pesantren.Melalui kitab ini, KH Bisri Mustofa berupaya melakukan reproduksi budaya santri dengan bekal habitus dan modal yang dimilikinya, dalam cakupan wilayah arena pesantren maupun arena kebangsaan Indonesia, dengan mengangkat tema besar tentang arti pentingnya budi pekerti mulia sebagaimana diajarkan Nabi SAW panutan para santri dan umat Islam pada umumnya.

\section{Simpulan}

Kitab Syi'ir Ngudi Susila karya KH Bisri Mustofa merupakan kitab yang memiliki tema besar tentang pentingnya budi pekerti luhur bagi 'bocah' (anak, murid, santri)atau'anak Islam'. Kitab ini merupakan wujud praktik sosok agen. Kitab ini kental sekali terpengaruh oleh habitus danmodal dari KH Bisri Mustofa sang penulis kitab sebagai sosok kyai dan juga politisi.

Munculnya ungkapan 'bocah' dan 'anak Islam' dalam kitab ini menunjukkan adanya perbedaan cakupan arena (ranah, field). Kata 'bocah' lebih mendominasi syair-syair pada Kelompok I, mulai bagian 1 sampai bagian 7. Sedangkan kata 'anak Islam' mendominasi syairsyair pada Kelompok II, yaitu bagian 8 dan 9. Habitus dan modal KH Bisri sebagai kyai pesantren nampaknya dominan mengisi ruang pemaknaan dalam Kelompok I. Sedangkan sebagai kyai-politisi dominan mengisi ruang pemaknaan dalam Kelompok II. Terdapat perbedaan cakupan arena yang dihadapi oleh sang agen. Pendek kata, habitus dan modal yang dimiliki agen sebagai kyai dan sebagai kyai-politisi banyak mempengaruhi isi kitab ini.

Baik sebagai kyai maupun sebagai kyai-politisi, nampaknya $\mathrm{KH}$ Bisri Mustofa tetap konsisten sebagai bagian dari masyarakat/kelas santri yang mengedepankan pembelajaran dan pembenakan budi pekerti luhur khas santri.Kitab ini membuktikan bahwa beliau berupaya melakukan reproduksi kultural santri.Pemikiran keIslaman KH Bisri Mustofa adalah pemikiran khas santri dan pesantren. Namun demikian, pemikiran keIslaman ini nampaknya meluas dan melampau sekat-sekat arena pondok pesantren dimana sang penulis hidup dan berkiprah harian sebagai pengasuh pondok pesantren. Pemikiran KH Bisri Mustofa juga memuat pemikiran kebangsaan Indonesia.Dengan kata lain, bahwa sebenarnya pemikiran KH Bisri Mustofa melalui praktis kitab Syi'ir Ngudi Susila ini menunjukkan bahwa kyai, santri, dan pesantren di bumi Nusantara itu sejak lama sudah menjunjung tinggi nilai-nilai ajaran budi pekerti mulia dan kebangsaan Indonesia. Kitab syair yang relatif kecil ini sangat layak diajarkan bagi kalangan santri dan masyarakat muslim Indonesia untuk menumbuhkembangkan budi pekerti mulia dan sekaligus jiwa kebangsaan Indonesia.

\section{DAFTAR PUSTAKA}

Agus Salim Chamidi.2017.Membedah Identitas Santri. Jurnal An Nahdhah, 11(1).

Volume: 2 NO. 2 .Tahun 2018

Manajemen Pendidikan Islam dan social

ISSN On_Line: 2580-9385

ISSN Cetak : 2581-0197

Jurnal Cakrawala IAINU Kebumen, Manajemen Pendidikan Islam (MPI) 
Ahmad Muhakammurohman. 2014. Pesantren: Kiai, Santri, dan Tradisi. Jurnal Ibda' Jurnal Kebudayaan Islam, 12(2).

Dani Wiryanti. 2009.Syiir Ngudi Susila Karya Kiai Bisri Mustofa (Suatu Kajian Stilistika),

Skripsi.Jurusan Sastra Daerah Fakultas Sastra dan Seni Rupa Universitas Sebelas Maret Surakarta.

Fejrian Yazdajird Iwanebel. 2014. Corak Mistis dalam Penafsiran KH. Bisri Mustofa, Telaah Analitis Tafsir Al-Ibriz. Jurnal Rasail, 1(1)

Kukuh Yudha Karnanta. 2013. Paradigma Teori Arena Produki Kultural Sastra, Kajian terhadap Pemikiran Pierre Bourdieu. Jurnal Poetika, 1(1).

Mangihut Siregar. 2016. Teori ‘Gado-Gado’ Pierre-Felix Bourdieu.Jurnal Studi Kultural, 1(2).

Moh.Hasim.2015. Ajaran Moral Syi'ir Ngudi Susilo dalam Membangun Karakter Anak.Jurnal Analisa Journal of Social Science and Religion.22 (2).

Mohamad Khamim Jazuli. 2017. Nilai-Nilai Pendidikan Akhlak dalam Kitab Syi’ir Ngudi Susilo Karya KH. Biri Mustofa.Skripsi . Jurusan Pendidikan Agama Islam Fakulta Tarbiyah dan Ilmu Keguruan IAIN Salatiga

Mohammad Adib. 2012. Agen dan Struktur dalam Pandangan Pierre Bourdieu. Jurnal BioKultur, 1(2).

Richard Harker, dkk. 2009. (Habitus $x$ Modal) + Ranah = Praktik, Pengantar Paling Komprehensif kepada Pemikiran Pierre Bourdieu. Terjemahan Pipit Maizier, Yogyakarta, Jalasutra.

Syaiful Fathoni. 2015. Pendidikan Akhlak Anak Usia Sekolah Dasar menurut KH. Bisri Mustofa dalam Syair Ngudi Susila Pitedhah Kanthi Terwela.Tesis.Malang, Universitas Islam Negeri Malik Ibrahim

Volume: 2 NO. 2 .Tahun 2018

ISSN On_Line: $2580-9385$

Manajemen Pendidikan Islam dan social

ISSN Cetak : 2581-0197

Jurnal Cakrawala IAINU Kebumen, Manajemen Pendidikan Islam (MPI) 